\title{
Perubahan Komposisi Kimia, Aktivitas Antioksidan, Vitamin C dan Mineral Tanaman Genjer (Limnocharis flava) Akibat Pengukusan
}

\author{
Nurjanah, Agoes M Jacoeb, Roni Nugraha, Marisa Permatasari, Tri Kalbu Ardiningrum Sejati \\ Departemen Teknologi Hasil Perairan, Fakultas Perikanan dan Ilmu Kelautan, \\ Institut Pertanian Bogor
}

Email: inun_thp10@yahoo.com

\begin{abstract}
Yellow velvetleaf (L. flava) is a type of aquatic plants commonly consumed by the public. Yellow velvetleaf steamed of processing products. The purpose of research was to determine the effect of steaming period on chemical composition, antioxidant activity, ascorbid acid, and minerals on yellow velvetleaf. Chemical composition of fresh yellow velvetleaf consisted of $93.92 \%$ of water, $0.20 \%$ of fat, $2.38 \%$ of protein, $0.70 \%$ of ash, $0.10 \%$ of acid soluble ash, $2.70 \%$ of carbohydrate and I.31\% crude fiber. Steaming caused a decrease in water levels and increased levels of fat, protein, ash, carbohydrate and crude fiber yellow velvetleaf. Phytochemical components of the three crude extracts yellow velvetleaf (fresh, steamed 3 and $5 \mathrm{~min}$ ) were steroids, saponins, phenol hydroquinone and reducing sugar. Antioxidant activity of the crude extracts was $131 \mathrm{ppm}$ and steaming for 3 minutes and 5 minutes increased IC50 value to $1350 \mathrm{ppm}$ and $3409 \mathrm{ppm}$, respectively. In conclusion steaming proses changed the antioxidant activity of yellow velvetleaf. Losses of ascorbid acid of fresh genjer were $3.20 \%$ and II.I5\% correspondingly after 3 and 5 minutes steaming. Beta carotene in fresh genjer decreased by 20.02\% (steamed 3 minutes) and $60.90 \%$ (steamed 5 minutes). Minerals respectively were decreased due to steaming. Hightest mineral loss happened to natrium with $70.44 \%$ (steamed 3 minutes) and $82.87 \%$ (steamed 5 minutes). Total minerals loss in steaming for 3 minutes was $26.60 \%$ and the for 5 minutes was $45.40 \%$.
\end{abstract}

Keyword: antioxidant activity, ascorbid acid , beta caroten , bioactive components, mineral, proximate, yellow velvetleaf (Limnocharis flava).

\section{PENDAHULUAN}

Kesibukan kerja di zaman sekarang menjadikan sebagian masyarakat lebih menyukai pola makan yang serba instan. Konsumsi makanan instan secara terus menerus dapat memberikan dampak negatif terhadap kesehatan. Makanan instan kebanyakan mengandung pengawet, pewarna, tinggi lemak, namun rendah serat yang berpotensi meninggalkan racun dalam tubuh serta sumber radikal bebas. Radikal bebas adalah atom atau molekul yang tidak stabil dan sangat reaktif karena mengandung satu atau lebih elektron tidak berpasangan pada orbital terluarnya (Andayani et al. 2008).

Antioksidan merupakan suatu zat yang dapat menangkal pengaruh radikal bebas yang bila masuk ke dalam tubuh dapat menyebabkan kerusakan (Salamah et al. 2008). Antioksidan terdapat dalam beberapa bentuk, di antaranya vitamin, mineral dan fitokimia. Genjer (L. flava) merupakan salah satu tumbuhan air yang berpotensi sebagai alternatif antioksidan alami.

Tanaman genjer merupakan tanaman asli wilayah tropis dan subtropis Amerika. 
Genjer merupakan tanaman air yang biasa dikonsumsi oleh masyarakat (Jacoeb et al. 2010). Salah satu proses pengolahan panas yang biasa digunakan untuk mengolah sayuran adalah pengukusan. Hasil penelitian Maisuthisakul et al. (2008) menunjukkan bahwa L. flava di wilayah Thailand mengandung total fenolik sebesar $5,4 \mathrm{mg}$ $\mathrm{GAE} / \mathrm{g}$ berat kering dan total flavonoid sebesar 3,7 mg RE/g berat kering.

Tumbuh-tumbuhan diketahui kaya dengan antioksidan misalnya vitamin $\mathrm{C}$, beta karoten, vitamin E, dan flavonoid. Sayuran berdaun telah dilaporkan memiliki peran penting dalam nutrisi manusia, terutama sebagai sumber vitamin $(A, B, C, E)$, mineral, dan serat makanan. Nilai gizi sayuran bervariasi sesuai dengan faktor lingkungan, perbedaan varietas, praktek budidaya, tahap pemanenan tanaman, metode penyimpanan, pengolahan, dan persiapan (Flyman dan Afolayan 2008).

\section{MATERIAL DAN METODE}

\section{Bahan dan Alat}

Bahan utama yang digunakan untuk penelitian ini adalah genjer (L. flava) yang diambil di desa Cikarawang, Kecamatan Darmaga, Kabupaten Bogor. Bahan-bahan yang dibutuhkan untuk analisis proksimat meliputi akuades, kjeltab jenis selenium, $\mathrm{H}_{2} \mathrm{SO}_{4}$ pekat, asam borat $\left(\mathrm{H}_{3} \mathrm{BO}_{3}\right) 4 \%$ yang mengandung indikator bromcherosol greenmethyl red (1:2) berwarna merah muda, $\mathrm{HCl}$ $0,0947 \mathrm{~N}$, pelarut lemak (n-heksana), $\mathrm{HCl}$ $10 \%$ dan $\mathrm{AgNO}_{3}$ 0,10 N. Alat yang digunakan meliputi labu lemak, kondensator, tabung Soxhlet, penangas air, labu Kjeldahl, destilator.

Bahan yang dibutuhkan untuk proses ekstraksi dan evaporasi adalah etanol $96 \%$. Bahan-bahan yang dibutuhkan untuk uji fitokimia meliputi pereaksi Wagner (uji alkaloid), pereaksi Meyer (uji alkaloid), pereaksi Dragendorff (uji alkaloid), kloroform, anhidra asetat, asam sulfat pekat (uji steroid), serbuk magnesium, amil alkohol (uji flavonoid), air panas, larutan $\mathrm{HCl} 2 \mathrm{~N}$ (uji saponin), etanol $70 \%$, larutan $\mathrm{FeCl}_{3} 5 \%$ (uji
Salah satu sumber vitamin yang banyak terdapat pada sayuran hijau adalah vitamin $\mathrm{C}$. Vitamin C merupakan vitamin yang paling mudah rusak karena mudah teroksidasi dan proses tersebut dipercepat oleh panas, sinar, alkali, enzim, oksidator serta oleh katalis tembaga dan besi. Oksidasi akan terhambat apabila vitamin $\mathrm{C}$ dibiarkan dalam kondisi asam atau suhu rendah (Rachmawati et al. 2009).

Penelitian mengenai tumbuhan air khususnya genjer, baik kandungan gizi maupun pengaruhnya setelah proses pemasakan saat ini masih sedikit. Informasi ini diperlukan dalam bidang pendidikan sebagai sumber informasi ilmiah. Salah satu informasi penting yang perlu diketahui adalah aktivitas antioksidan, jumlah vitamin dan mineral pada genjer baik sebelum maupun setelah proses pemasakan.

fenol hidrokuinon), peraksi Molisch, asam sulfat pekat (uji Molisch), pereaksi Benedict (uji Benedict), pereaksi Biuret (uji Biuret) dan larutan Ninhidrin $0,10 \%$ (uji Ninhidrin). Alat yang digunakan meliputi timbangan digital, kertas saring, orbital shaker, tabung Erlenmeyer, rotary vacuum evaporator, gelas piala dan tabung reaksi.

Bahan-bahan yang dibutuhkan untuk uji aktivitas antioksidan, yaitu ekstrak kasar genjer, kristal 1,1-difenil-2-pikrilhidrazil (DPPH), etanol dan BHT (butylated hydroxytoluena) sebagai pembanding. Alat yang digunakan meliputi tabung reaksi, ELLISA reader, microplate, multipipette, dan labu takar.

\section{Lingkup Penelitian}

Tahap penelitian terdiri atas pengukusan, analisis proksimat, ekstraksi, analisis fitokimia, Vitamin C dan aktivitas antioksidan dengan metode DPPH.

\section{Pengukusan}

Proses pengukusan genjer dilakukan terhadap bagian daun dan batang. Proses pengukusan bertujuan untuk menentukan pengaruh proses pengukusan terhadap 
proksimat, fitokimia, vitamin C dan aktivitas antioksidan genjer. Pengukusan dilakukan selama menit 3 dan 5 menit hingga daun terlihat agak layu tetapi warna genjer tetap hijau.

\section{Analisis proksimat}

Analisis proksimat terdiri atas analisis kadar air, abu, lemak, protein (AOAC 2005). Analisis kadar abu larut asam mengacu pada BSN (2010) dan kadar serat mengacu pada BSN (1992).

\section{Ekstraksi (Quinn 1988)}

Genjer segar dan genjer yang telah mengalami pengukusan dikeringkan dengan panas matahari. Genjer yang telah dikeringkan tersebut kemudian dihancurkan dengan blender sehingga didapat tekstur yang halus. Tahap selanjutnya adalah ekstraksi bahan aktif. Metode ekstraksi yang digunakan adalah metode ekstraksi tunggal. Pelarut yang digunakan dalam penelitian ini yaitu etanol $96 \%$.

\section{Analisis fitokimia (Harborne 1984)}

Uji fitokimia dilakukan untuk mengetahui ada tidaknya komponen-komponen bioaktif yang terdapat pada ekstrak kasar genjer yang memiliki aktivitas antioksidan. Uji fitokimia meliputi uji alkaloid, uji steroid/triterpenoid, flavonoid, saponin, fenol hidrokuinon, Molisch, Benedict, Biuret dan Ninhidrin.

\section{Analisis aktivitas antioksidan dengan metode DPPH (Salazar et al. 2009)}

Analisis aktivitas uji aktioksidan dilakukan menggunakan metode DPPH (1,1-difenil-2pikrilhidrazil). Ekstrak kasar genjer dari hasil ekstraksi tunggal menggunakan pelarut etanol dilarutkan dalam etanol. Larutan DPPH yang digunakan, dibuat dengan melarutkan kristal $\mathrm{DPPH}$ dalam pelarut etanol $1 \mathrm{mM}$. Pembanding yang digunakan adalah BHT. Sampel dan pembanding dipindahkan dalam microplate sebanyak $100 \mathrm{~mL}$ menggunakan pipet mikro dan ditambah $100 \mathrm{~mL}$ DPPH. Campuran diinkubasi pada suhu $37^{\circ} \mathrm{C}$ selama 30 menit dan diukur absorbansinya dengan menggunakan ELISA Reader.

$\begin{array}{clll}\text { Hasil uji } & \text { dari } & \text { metode } & \mathrm{DPPH} \\ \text { diinterpretasikan } & \text { dalam } & \text { parameter } & \mathrm{IC}_{50}\end{array}$

(Inhibition Concentration 50) yang didefinisikan sebagai konsentrasi larutan substrat atau sampel yang akan menyebabkan tereduksi aktivitas DPPH sebesar $50 \%$. Pada metode ini, larutan DPPH yang berperan sebagai radikal bebas akan bereaksi dengan senyawa antioksidan sehingga DPPH akan berubah menjadi diphenilpycrilhydrazine yang bersifat nonradikal.

\section{Analisis vitamin C}

Vitamin C diekstraksi menurut metode modifikasi dari Abdulnabi et al. (1997). Sebanyak 10 gram sampel dihomogenkan dengan asam metafosfat $0,3 \mathrm{M}$ dan asam asetat 1,4 M. Campuran ditempatkan dalam gelas ukur (dibungkus dengan aluminium foil) dan dihomogenkan dengan orbital shacker pada kecepatan $100 \mathrm{rpm}$ selama 15 menit pada suhu ruang. Campuran tersebut kemudian disaring melalui kertas Whatman No. 4 untuk mendapatkan ekstrak. Semua sampel diekstraksi dalam tiga ulangan. Dua teknik yang digunakan untuk mengidentifikasi vitamin C pada kromatogram adalah membandingkan waktu retensi dan spiking tes dengan L-asam askorbat.

\section{Analisis mineral}

Pengujian analisis mineral dilakukan melalui pengabuan basah terlebih dahulu. Proses pengabuan basah dilakukan dengan sampel ditimbang sebanyak $1 \mathrm{~g}$, kemudian dimasukkan ke dalam erlenmeyer $150 \mathrm{~mL}$. Sebayak $5 \mathrm{~mL} \mathrm{HNO}_{3}$ ditambahkan ke dalam labu dan dibiarkan selama 1 jam. Labu ditempatkan di atas hotplate selama \pm 4 jam dan dibiarkan selama semalam dalam keadaan sampel tertutup, kemudian tambahkan 0,4 $\mathrm{mL} \mathrm{H}_{2} \mathrm{SO}_{4}$ pekat, dipanaskan di atas hotplate sampai larutan berkurang (lebih pekat). Larutan kemudian ditambahkan 2-3 tetes campuran $\mathrm{HClO}_{4}$ dan $\mathrm{HNO}_{3}$ (2:1), sampel tetap berada di atas hotplate karena pemanasan terus berjalan hingga terjadi perubahan warna. Pemanasan tetap dilanjutkan selama 10-15 menit. Sampel dipindahkan, didinginkan dan ditambahkan 2 $\mathrm{mL}$ akuades dan 0,6 $\mathrm{mL} \mathrm{HCl}$ pekat. Larutan contoh kemudian diencerkan menjadi $100 \mathrm{~mL}$ 
dalam labu takar. Sejumlah larutan stok standar dari masing-masing mineral diencerkan menggunakan akuades sampai konsentrasinya berada dalam kisaran kerja logam yang diinginkan.

\section{HASIL DAN PEMBAHASAN Karakteristik genjer}

Genjer mempunyai daun yang berbentuk membulat dan terdapat lapisan lilin pada bagian daun. Tumbuhan genjer yang subur ukurannya bisa mencapai lebar telapak tangan orang dewasa yang ditopang batang bersegi tiga yang berongga di dalamnya. Batangnya berwarna hijau muda dan tebal dengan diameter sekitar 7,4 cm. Genjer yang diperoleh dalam penelitian ini hidup di lingkungan dengan air yang jernih, kedalaman air 3 sampai $4 \mathrm{~cm}$ dan suhu perairan $27^{\circ} \mathrm{C}$.

Rendemen adalah persentase perbandingan antara berat bagian bahan yang dapat dimanfaatkan dengan berat total bahan. Nilai rendemen genjer segar bagian daun, batang dan akar disajikan pada Gambar 1 . Hasil perhitungan rendemen menunjukkan bahwa rendemen daun, batang dan akar genjer berturut-turut adalah 9,84\%, 68,65\% dan $20,49 \%$. Perhitungan rendemen apabila dijumlahkan tidak mencapai $100 \%$. Hal ini disebabkan adanya bagian yang tidak dapat dimanfaatkan pada penelitian ini.

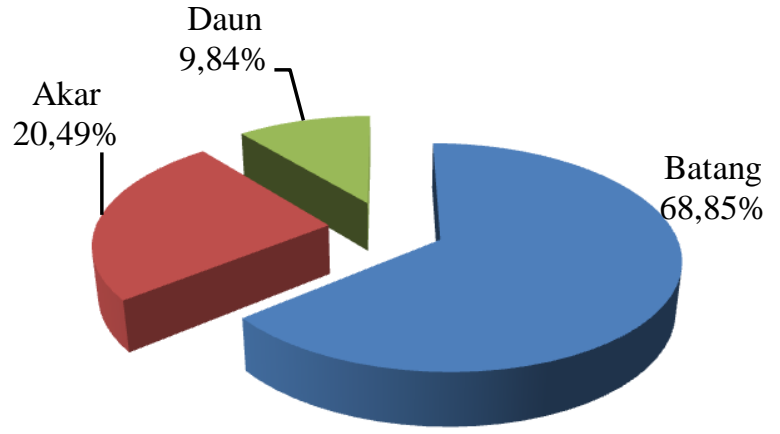

Gambar 1. Rendemen genjer

Hasil analisis proksimat kadar air, lemak, protein, abu, abu tidak larut asam, karbohidrat, serat kasar dan kadar karbohidrat genjer diperoleh melalui perhitungan by difference disajikan pada Tabel 1. Proses pengolahan pada sayuran dapat menyebabkan perubahan kadar air. Kadar air genjer segar mengalami perubahan setelah proses pengukusan dari 93,92 \% menjadi $92,49 \%$ pada pengukusan 3 menit dan 91,18 $\%$ pada pengukusan 5 menit. Hasil analisis kadar air genjer segar pada penelitian ini lebih tinggi dibandingkan hasil penelitian Saupi et al. (2009) sebesar 79,34\%. Perubahan kadar air ini dapat disebabkan oleh mudahnya air menguap ketika mengalami proses pemanasan. Transfer panas dan pergerakan aliran air maupun udara menyebabkan proses penguapan dan pengeringan pada bahan makanan.

Tabel 1.Komposisi kimia genjer segar dan kukus

\begin{tabular}{|c|c|c|c|}
\hline \multirow{2}{*}{ Komponen } & \multicolumn{3}{|c|}{ Kandungan (\% berat basah) } \\
\hline & Segar & Kukus menit ke-3 & Kukus menit ke-5 \\
\hline Kadar air & $93,92 \pm 0,13$ & $92,49 \pm 0,04$ & $91,18 \pm 0,07$ \\
\hline Kadar lemak & $0,20 \pm 0,00$ & $0,29 \pm 0,13$ & $0,39 \pm 0,01$ \\
\hline Kadar protein & $2,38 \pm 0,01$ & $2,81 \pm 0,52$ & $2,03 \pm 0,33$ \\
\hline Kadar abu & $0,70 \pm 0,14$ & $0,89 \pm 0,13$ & $0,99 \pm 0,00$ \\
\hline Kadar abu tidak larut asam & $0,10 \pm 0,00$ & $0,10 \pm 0,00$ & $0,10 \pm 0,00$ \\
\hline Kadar serat kasar & $1,31 \pm 0,06$ & $1,34 \pm 0,03$ & $1,53 \pm 0,17$ \\
\hline Kadar karbohidrat & $2,70 \pm 0,00$ & $3,42 \pm 0,49$ & $5,31 \pm 0,39$ \\
\hline \multirow[t]{2}{*}{$\begin{array}{l}\text { Perubahan kadar lemak } \\
\text { oporsional terjadi pada genjer set }\end{array}$} & $\begin{array}{l}\text { secara } \\
\text { lah }\end{array}$ & \multicolumn{2}{|c|}{$\begin{array}{l}\text { proses pengukusan. Kadar lemak genje } \\
\text { segar sebesar } 0,20 \% \text { berubah menjadi } 0,39 \%\end{array}$} \\
\hline & & $\begin{array}{l}\text { setelah mengalami } \\
\text { menit. }\end{array}$ & engukusan selama \\
\hline
\end{tabular}


Kadar protein genjer segar pada penelitian ini sebesar 2,38\%. Nilai ini lebih tinggi dibandingkan dengan kadar protein genjer hasil penelitian Saupi et al. (2009) sebesar $0,28 \%$. Hal ini diduga karena perbedaan habitat dan kondisi genjer yang digunakan. Pengukusan menyebabkan penurunan kadar protein genjer. Kadar protein genjer mengalami peningkatan setelah pengukusan selama 3 menit dari 2,38\% menjadi $2,81 \%$, kemudian mengalami penurunan setelah pengukusan selama 5 menit menjadi 2,03\%. Jacoeb et al. (2010) menyatakan bahwa peningkatan presentasi kadar protein pada genjer setelah pengukusan diduga karena adanya penguraian tanin pada daun dan batang genjer.

Kadar abu genjer sebesar $0,70 \%$ berubah menjadi $0,85 \%$ dan $0,99 \%$ akibat proses pengukusan selama 3 dan 5 menit. Kadar abu mengalami perubahan karena adanya air yang keluar akibat proses pengukusan. Mineral-mineral yang terkandung dalam tanaman genjer yaitu kalsium, fosfor, besi, natrium, kalium, tembaga, dan seng ikut keluar bersama dengan keluarnya air akibat proses pengukusan.

Hasil pengujian kadar abu tidak larut asam menunjukkan bahwa genjer mengandung residu abu tak larut asam sebesar 0,10\% dari ketiga sampel. Kadar abu tidak larut asam ini diduga berasal dari material-material abu yang tidak larut asam yang terdapat pada substrat perairan tempat genjer tumbuh. Abu tidak larut asam dicerminkan oleh adanya kontaminasi mineral atau logam yang tidak larut asam dalam suatu produk (Basmal et al. 2003).

Genjer segar memiliki kandungan serat (basis basah) sebesar $1,31 \%$ sedangkan genjer yang telah mengalami proses pengukusan selama 3 dan 5 menit memiliki kandungan serat sebesar $1,34 \%$ dan $1,53 \%$. Peningkatan kadar serat diduga karena adanya penurunan kadar air yang terdapat pada daun dan tangkai tidak diikuti dengan penurunan kadar serat sehingga kadar serat pada genjer yang mengalami pengukusan tidak mengalami penurunan.

Hasil perhitungan by difference memberikan nilai karbohidrat sebesar 2,70\% pada genjer segar $3,42 \%$ pada pengukusan selama 3 menit dan $5,31 \%$ pada proses pengukusan selama 5 menit. Nilai karbohidrat pada genjer yang mengalami pengukusan terjadi peningkatan, hal ini diduga karena adanya penurunan kadar air dan komponen lainnya

\section{Komponen bioaktif genjer}

Genjer segar memiliki persentase rendemen ekstrak terkecil yaitu $9,26 \%$, sedangkan ekstrak genjer yang mengalami pengukusan selama 5 menit memiliki rendemen terbesar yaitu $13,53 \%$.(Gambar 2) Proses pengukusan menyebabkan serat-serat yang terdapat pada genjer menjadi lebih lunak sehingga kelarutan komponen dalam pelarut juga berbeda. Hal ini diduga menyebabkan serat-serat yang lebih lunak memudahkan komponen bioaktif yang terdapat pada genjer lebih mudah larut pada pelarutnya. Hasil uji fitokimia pada masing-masing ekstrak kasar genjer disajikan pada Tabel 2.

Pengaruh pengukusan tidak memberikan perbedaan komponen bioaktif yang dihasilkan pada ekstrak genjer. Komponen bioaktif pada ekstrak genjer dari ketiga perlakuan meliputi steroid, saponin, fenol hidroquinon dan gula pereduksi.

Steroid merupakan salah satu senyawa kimia yang banyak digunakan dalam bidang pengobatan. Steroid ini diduga memiliki efek peningkat stamina tubuh (aprodisiaka) dan antiinflamasi (Nurjanah et al. 2011). Proses pengukusan selama 3 dan 5 menit yang dilakukan pada genjer tidak terlalu berpengaruh secara kualitatif terhadap kandungan steroid. 


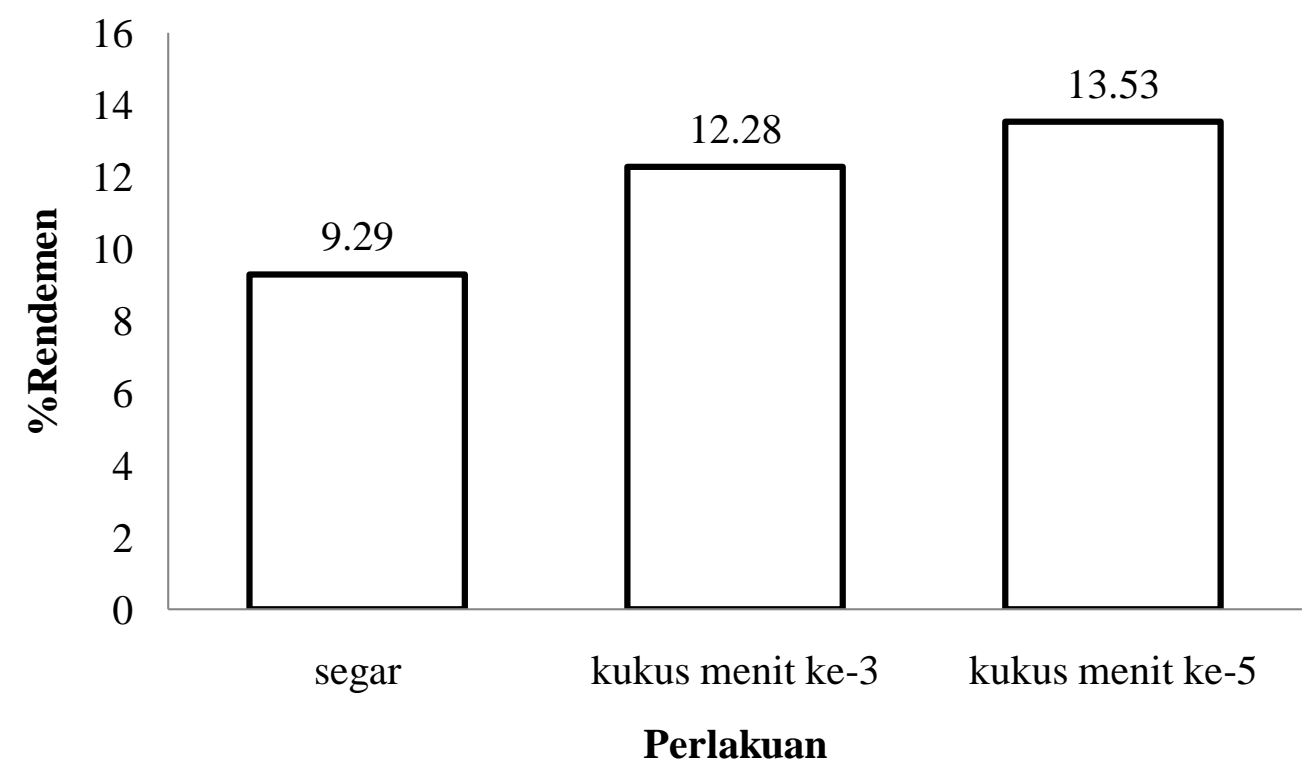

Gambar 2. Rendemen ekstrak genjer (\%)

Hasil penelitian menunjukkan bahwa ekstrak genjer segar, kukus 3 dan 5 menit terdeteksi adanya saponin dan gula pereduksi. Hal ini dibuktikan dengan adanya busa yang terbentuk untuk uji saponin dan terbentuk warna hijau pada uji gula pereduksi. Hasil penelitian Nurjanah et al. (2009) menunjukan analisis komponen fitokimia ekstrak tepung lintah laut mengandung senyawa alkaloid, saponin, steroid dan fenol yang diduga berperan dalam menurunkan kolesterol total maupun LDL.

Proses pengukusan selama 3 dan 5 menit yang dilakukan pada genjer tidak mengalami perubahan secara kualitatif terhadap kandungan gula pereduksi. Gula pereduksi merupakan bagian primer dari metabolisme tumbuhan. Hal ini sesuai dengan Koche et al. (2010) menyatakan bagian primer terdiri atas gula, asam amino, protein dan klorofil.

Hasil penelitian menunjukkan adanya komponen fenol hidrokuinon pada ekstrak kasar genjer segar dan genjer yang mengalami pengukusan selama 3 dan 5 menit. Komponen fenol dapat bertindak sebagai terminator oksidasi dengan cara menangkap radikal untuk membentuk radikal stabil. Hasil penelitian Maisuthisakul et al. (2008) menunjukan adanya total fenol sebesar 5,4 mgGAE/g BDD pada tanaman genjer.

Tabel 2. Hasil uji fitokimia berbagai ekstrak genjer

\begin{tabular}{|c|c|c|c|c|}
\hline \multirow[b]{2}{*}{ Uji Fitokimia } & \multicolumn{3}{|c|}{ Ekstrak } & \multirow[b]{2}{*}{ Keterangan } \\
\hline & Segar & $\begin{array}{l}\text { K. menit } \\
\text { ke-3 }\end{array}$ & $\begin{array}{l}\text { K. menit } \\
\text { ke-5 }\end{array}$ & \\
\hline Akaloid & - & - & - & $\begin{array}{l}\text { Tidak terdapat endapan putih } \\
\text { alam pereaksi Meyer, endapan } \\
\text { coklat dalam pereaksi Wagner } \\
\text { dan endapan merah dalam } \\
\text { pereaksi Dragendorff }\end{array}$ \\
\hline Steroid & + & + & + & Terbentuk warna hijau kebiruan \\
\hline Flavonoid & - & - & - & $\begin{array}{l}\text { Tidak terbentuk lapisan amil } \\
\text { alcohol }\end{array}$ \\
\hline
\end{tabular}




\begin{tabular}{cccll} 
Saponin & + & + & + & Terbentuk busa \\
Molisch & - & - & - & Tidak terbentuk lapisan berwarna \\
& & & & ungu tua \\
Benedict & + & + & + & Warna hijau \\
Fenol & + & + & + & Terbentuk warna hijau tua \\
Hidroquinon & & & & \\
Ninhidrin & - & - & - & Tidak terbentuk warna biru \\
Biuret & - & - & - & Tidak terbentuk warna ungu \\
\hline
\end{tabular}

\section{Aktivitas Antioksidan Genjer dengan Metode DPPH}

Nilai rata-rata $\mathrm{IC}_{50} \mathrm{BHT}$ dan ekstrak kasar genjer (segar, kukus 3 dan 5 menit) disajikan pada Gambar 3. Semakin kecil nilai $I_{50}$ menunjukkan bahwa aktivitas antioksidannya semakin tinggi (Molyneux 2004). Ekstrak kasar genjer segar memiliki aktivitas antioksidan yang lebih besar dari dua ekstrak kasar genjer lainnya, ditandai dengan nilai $\mathrm{IC}_{50}$-nya yang terkecil, yaitu $131 \mathrm{ppm}$. Ekstrak genjer merupakan ekstrak yang memiliki aktivitas antioksidan yang paling lemah ditunjukkan dengan nilai $\mathrm{IC}_{50}$-nya yang terbesar, yaitu 3409 ppm. Pembanding BHT memiliki nilai $\mathrm{IC}_{50}$ terendah yaitu $3,88 \mathrm{ppm}$. Nilai $I_{50}$ pada genjer segar lebih rendah dibandingkan dengan penelitian Sakong et al. (2011) yang menunjukan total aktivitas antiokasidan pada daun genjer sebesar 317 ppm.

Proses pengukusan mempengaruhi nilai $\mathrm{IC}_{50}$ dari genjer, semakin lama waktu pengukusan semakin besar nilai $\mathrm{IC}_{50}$. Proses pengolahan akan memberikan perubahan

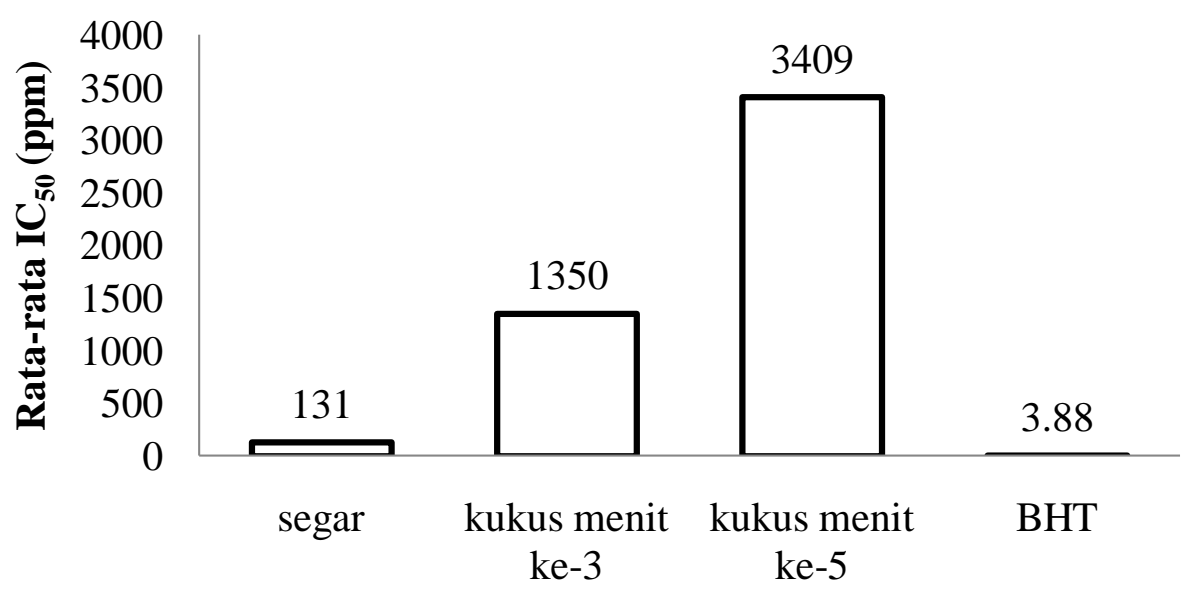

Perlakuan

Gambar 3. Nilai $I C_{50}$ genjer segar dan kukus

dan antioksidan dalam sayuran yang telah

Karakteristik secara fisik maupun komposisi kimia dalam sayuran. Pengukusan dapat menurunkan kadar zat gizi makanan yang besarnya bergantung pada cara mengukus dan jenis makanan yang dikukus. Hasil penelitian menunjukkan Proses pengolahan dapat mengakibatkan kandungan fitokimia diolah lebih rendah daripada sayuran dalam keadaan segar (Azizah et al. 2009).

Ekstrak kasar genjer kukus memiliki aktivitas antioksidan yang sangat lemah karena nilai $I_{50}$-nya lebih besar dari 0,20 $\mathrm{mg} / \mathrm{mL}$ atau $200 \mathrm{ppm}$, hal ini jauh berbeda dengan aktivitas antioksidan BHT sebagai pembanding. Hasil penelitian ini jauh lebih 
baik dibandingkan hasil penelitian Raghu et al. (2010) terhadap sepuluh macam sayuran yang biasa dikonsumsi di India, nilai $\mathrm{IC}_{50}$-nya berkisar 950 - 4750 ppm.

\section{Kandungan Vitamin C Genjer}

Kandungan vitamin $\mathrm{C}$ genjer segar lebih tinggi jika dibandingkan dengan kandungan vitamin $\mathrm{C}$ genjer setelah proses pengukusan. Kandungan vitamin $C$ genjer segar dalam berat kering adalah sebesar $46,63 \mathrm{mg} / 100 \mathrm{~g}$. Hal ini berbeda dengan yang dikemukakan oleh Direktorat Gizi, Departemen Kesehatan (1992), kandungan vitamin C genjer segar (Limnocharis flava) adalah sebesar $54 \mathrm{mg} / 100$ g. Perbedaan tersebut diduga karena perbedaan lokasi tumbuh dan keadaan alam dari tempat hidup genjer. Kandungan vitamin $C$ pada genjer segar ini tergolong sedang. Somsub et al. (2007) menyatakan bahwa kandungan vitamin $\mathrm{C}$ dalam sampel sayur dibagi dalam tiga tingkatan yaitu kategori tinggi $(71,8 \mathrm{mg} / 100 \mathrm{~g})$, sedang $(9,6-71,6$ $\mathrm{mg} / 100 \mathrm{~g}$ ), dan rendah (kurang dari 9,6 $\mathrm{mg} / 100 \mathrm{~g}$ ). Vitamin $\mathrm{C}$ diproduksi oleh tumbuhan dalam jumlah yang besar. Fungsi vitamin $C$ bagi tumbuhan adalah sebagai agen antioksidan yang dapat menetralkan singlet oksigen yang sangat reaktif, berperan dalam pertumbuhan sel, berfungsi seperti hormon, dan ikut berperan dalam proses fotosintesis (Davey et al. 2006).

Kandungan vitamin $\mathrm{C}$ genjer mengalami penurunan setelah pengukusan, nilai vitamin $C$ pada genjer segar sebesar $46,63 \mathrm{mg} / 100 \mathrm{~g}$ menurun setelah pengukusan 3 menit menjadi $43,81 \mathrm{mg} / 100 \mathrm{~g}$ dan pada pengukusan 5 menit semakin menurun menjadi 37,34 $\mathrm{mg} / 100 \mathrm{~g}$. Pengukusan genejr selama 3 menit menyebabkan kadar vitamin $\mathrm{C}$ menurun sebesar $6,05 \%$ dan pada pengukusan 5 menit menurun sebesar 20,06\%, hal ini menunjukkan bahwa semakin lama waktu pengukusan menyebabkan kandungan vitamin C semakin menurun. Oboh (2005) menyatakan bahwa pengolahan berbagai makanan dengan metode konvensional membawa kerugian terhadap kandungan vitamin $\mathrm{C}$ pada sayuran berdaun. Penurunan kandungan vitamin $\mathrm{C}$ dapat dikaitkan dengan fakta bahwa vitamin $C$ larut dalam air dan pada saat yang sama tidak tahan terhadap panas. Naidu (2003) menyatakan bahwa kebutuhan vitamin $\mathrm{C}$ berdasarkan U.S. RDA antara lain untuk pria dan wanita sebanyak 60 $\mathrm{mg} /$ hari, bayi sebanyak $35 \mathrm{mg} / \mathrm{hari}$, ibu hamil sebanyak $70 \mathrm{mg} / \mathrm{hari}$, dan ibu menyusui sebanyak $95 \mathrm{mg} / \mathrm{hari}$.

Kandungan beta karoten genjer segar dan setelah pengukusan mengalami penurunan. Nilai beta karoten genjer segar dalam berat kering sebesar $69,62 \mathrm{mg} / 100 \mathrm{~g}$, berubah setelah pengukusan 3 menit menjadi 44,87 $\mathrm{mg} / 100 \mathrm{~g}$, dan pada pengukusan 5 menit menjadi 18,44 mg/100 g. Olemo et al. (2011) menyatakan bahwa kehilangan beta karoten dengan presentase rendah (10\%) diamati pada Solanum incanum dapat dikaitkan dengan metode pengolahan yang berbeda.

\section{Kandungan Mineral Genjer}

Kandungan mineral makro tertinggi dalam berat kering pada genjer segar terdapat pada kalium $(6.786,18 \mathrm{mg} / 100 \mathrm{~g})$ dan mineral terendah adalah natrium $(574,34 \mathrm{mg} / 100 \mathrm{~g})$. Kandungan mineral mikro tertinggi dalam basis kering pada genjer segar adalah besi $(1.924,69 \mathrm{mg} / 100 \mathrm{~g})$ dan terendah adalah seng $(749,48 \mathrm{mg} / 100 \mathrm{~g})$. Arifin (2008) menyatakan bahwa kandungan mineral di dalam setiap bahan makanan berbeda-beda bergantung kepada jenis dan kondisi hidupnya.

Kandungan mineral Genjer setelah dilakukan proses pengukusan mengalami perubahan (Tabel 3). Mineral yang mengalami penurunan jumlah setelah pengukusan selama 3 menit adalah kalsium (Ca) 811,89 $\mathrm{mg} / 100 \mathrm{~g}$, natrium (Na) 169,77 mg/100 g, kalium (K) 5.146,47 mg/100 g, fosfor (P) $2.535,95 \mathrm{mg} / 100 \mathrm{~g}$, seng (Zn) 302,30 mg/100 $\mathrm{g}$, dan besi (Fe) $1.866,48 \mathrm{mg} / 100 \mathrm{~g}$. Mineral yang mengalami penurunan jumlah setelah pengukusan selama 5 menit adalah kalsium (Ca) 445,76 mg/100 g, natrium ( $\mathrm{Na}$ ) 98,35 $\mathrm{mg} / 100 \mathrm{~g}$, kalium (K) 3.744,55 mg/100 g, 
fosfor (P) 982,82 mg/100 g, seng (Zn) 262,32 $\mathrm{mg} / 100 \mathrm{~g}$, dan besi (Fe) $1.200,92 \mathrm{mg} / 100 \mathrm{~g}$. Rahayu et al. (2010) menyatakan bahwa ketika makanan dimasak, diproses, atau disimpan, mineral dapat bergabung dengan komponen kimia makanan lain atau bahkan larut akibat pemanasan. Sama halnya dengan vitamin, variasi kandungan mineral alamiah makanan mentah dan metode memasak yang berbeda dapat menghasilkan variasi kadar mineral. Mineral pada umumnya tidak peka terhadap panas, tetapi rentan terhadap pencucian atau pengolahan yang melibatkan air seperti perebusan dan pengukusan. Penurunan mineral selama pencucian dapat diperkecil dengan mengurangi jumlah air yang digunakan untuk memasak bahan makanan.

Tabel 3. Kandungan mineral genjer segar dan kukus

\begin{tabular}{cccc}
\hline Komposisi & \multicolumn{3}{c}{ Nilai (mg/100 g) } \\
\cline { 2 - 4 } mineral & Segar* & Kukus 3 menit & Kukus 5 menit \\
\hline Mineral makro & & & \\
Fosfor (P) & $3.858,55 \pm 139,21^{\mathrm{a}}$ & $2.535,95 \pm 37,59^{\mathrm{a}}$ & $982,82 \pm 813,94^{\mathrm{b}}$ \\
Kalsium (Ca) & $1.892,25 \pm 1,86^{\mathrm{a}}$ & $811,89 \pm 7,88^{\mathrm{c}}$ & $445,76 \pm 53,86^{\mathrm{b}}$ \\
Kalium (K) & $6.786,18 \pm 50,97^{\mathrm{a}}$ & $5.146,47 \pm 27,53^{\mathrm{c}}$ & $3.744,55 \pm 41,30^{\mathrm{b}}$ \\
Natrium (Na) & $574,34 \pm 25,57^{\mathrm{a}}$ & $169,77 \pm 4,28^{\mathrm{c}}$ & $98,35 \pm 3,04^{\mathrm{b}}$ \\
Mineral mikro & & & \\
Besi (Fe) & $1.924,69 \pm 83,59^{\mathrm{a}}$ & $1.866,48 \pm 11,57^{\mathrm{a}}$ & $1.200,92 \pm 57,61^{\mathrm{b}}$ \\
Seng (Zn) & $749,48 \pm 18,19^{\mathrm{a}}$ & $302,30 \pm 10,63^{\mathrm{c}}$ & $262,32 \pm 12,33^{\mathrm{b}}$ \\
\hline Keten
\end{tabular}

Keterangan : Angka yang diikuti oleh huruf yang sama menunjukkan perbedaan waktu pengukusan tidak memberikan pengaruh yang berbeda nyata terhadap komposisi kimia $(p<0,05)$

\section{KESIMPULAN}

Ekstrak kasar genjer segar dan genjer yang mengalami pengukusan (selama 3 dan 5 menit) memiliki aktivitas antioksidan. Ekstrak genjer segar memiliki antioksidan paling tinggi dengan nilai $\mathrm{IC}_{50}$ sebesar 131 ppm. Komponen bioaktif yang terdapat pada ketiga ekstrak kasar genjer meliputi steroid, saponin, gula pereduksi dan fenol hidrokuinon. Secara kualitatif proses pengukusan tidak menyebabkan perubahan pada komponen bioaktif tetapi mempengaruhi aktivitas antioksidan.

Kandungan vitamin $\mathrm{C}$ dan beta karoten genjer segar dan setelah proses pengukusan mengalami penurunan, semakin menurun dengan meningkatnya waktu pemasakan. Kandungan mineral makro terbesar pada genjer segar adalah kalium (K) sebesar 6.786,18 $\mathrm{mg} / 100 \mathrm{~g}$ dan terendah adalah natrium ( $\mathrm{Na}$ ) yaitu sebesar $574,34 \mathrm{mg} / 100 \mathrm{~g}$, sedangkan mineral mikro terbesar adalah besi (Fe) yaitu sebesar $1.924 \mathrm{mg} / 100 \mathrm{~g}$. Mineral yang diteliti secara keseluruhan mengalami penurunan setelah proses pengukusan. Waktu pengukusan terbaik adalah 3 menit karena zat gizi yang hilang pada pengukusan 3 menit tidak sebesar pada pengukusan 5 menit.

\section{DAFTAR PUSTAKA}

[AOAC] Association of Official Analytical Chemist. 2005. Official Method of Analysis of The Association of Official Analytical of Chemist. Arlington: The Association of Official Analytical Chemist, Inc.

[BSN] Badan Standardisasi Nasional. 1992. Cara uji kimia-bagian I: Penentuan Kadar Serat Pangan SNI 0I-289I-1992. Jakarta: Standardisasi Nasional Indonesia.

[BSN] Badan Standardisasi Nasional. 2010. Cara uji kimia-nagian I: Penentuan Kadar Abu dan Abu Tidak Larut Asam pada Produk Perikanan SNI2354.I-20 I0. Jakarta: Standardisasi Nasional Indonesia.

Abdulnabi AA, Emhemed AH, Hussein G. Daood, $P C$ ter $A B$. 1997. Determination of antioxidant vitamins in tomatoes. Journal Food Chemistry. 60 (2): 207-2I 2 . 
Andayani R, Lisawati Y, Maimunah. 2008. Penentuan aktivitas antioksidan, kadar fenolat total dan likopen pada buah tomat (Solanum Lycopersicum L). Jurnal Sains dan Teknologi Farmasi. 13(I): I-9.

Arifin Z. 2008. Beberapa unsur mineral esensial mikro dalam sistem biologi dan metode analisisnya. Jurnal Litbang Pertanian. 27 (3): 99105.

Azizah AH, Wee KC, Azizah O, Azizah M. 2009. Effect of boiling and stir frying on total phenolics, carotenoids and radical scavenging activity of pumpkin (Cucurbita moschato). International Food Research Journal. 16: 45$5 \mathrm{I}$.

Basmal J, Syarifudin, Ma'ruf WF. 2003. Pengaruh konsentrasi larutan potassium hidroksida terhadap mutu kappa-karaginan yang di ekstraksi dari euchema cottonii. Jurnal Penelitian Perikanan Indonesia. 9(5):95-I03.

Davey MW, Kenis K, Keulemans J. 2006. Genetic control of fruit vitamin $C$ contents. Journal Plant Physiology. I42: 343-35I.

Direktorat Gizi Departemen Kesehatan RI. 1992. Daftar Komposisi Bahan Pangan. Jakarta: Bhatara Karya Aksara.

Flyman MV, Afolayan AJ. 2008. Effect of plant maturity on the mineral content of the leaves of Momordica balsamina L. and Vigna unguiculata subp. sesquipedalis (L.) Verdc. Journal of Food Quality. 3I(5): 66I-67I.

Harborne JB. 1984. Phytochemical Methods. Ed ke-2. New York: Chapman and Hall.

Jacoeb AM, Abdullah A, Rusydi R. 2010. Karakteristik mikroskopis dan komposisi tanaman genjer (Limnocharis flava) dari Situ Gede Bogor. Jurnal Sumberdaya Perairan. 4 (2): I-6.

Koche D, Shirsat R, Imran S, Bhadange DG. 2010. Phytochemical screening of eight traditionally used ethnomedicinal plants from Akola district (MS) India. International Journal of Pharma and Bio Sciences. I (4):253-256.

Maisuthisakul P, Pasuk S, Ritthiruangdej P. 2008. Relationship between antioxidant properties and chemical composition of some thai plants. Journal of Food Composition and Analysis. 21: 229-240.
Molyneux P. 2004. The use of the stable free radical dyhenylpicrylhydrazil (dpph) for estimating antioxidant activity. Songklanakarin Journals of Science and Technology. 26:211219.

Naidu KA. 2003. Vitamin $C$ in human health and disease is still a mystery ? An overview. Nutrition Journal. 2: I-7.

Nurjanah, Izzati L, Abdullah A. 20II. Aktivitas antioksidan dan komponen bioaktif kerang pisau (Solen spp). Jurnal IImu Kelautan. 16 (3): I19-124.

Nurjanah, Hardjito L, Monintja DR, Bintang M, Agungpriyono DR. 2009. Lintah laut (Discodoris sp) sebagai antikolesterolemia pada kelinci New Zealand white. Jurnal Kelautan Nasional. 2:31-42.

Oboh G. 2005. Effect of blanching on the antioxidant properties of some tropical green leafy vegetables. LWT-Food Science and Technology. 38: 5I3-517.

Olemo BO, Elemo GN, Senaike AO, Erukainure OL. 20I I. Effect of various pocessing methods on beta-caroten and ascorbic acid content of same green leafy vegetables. Journal Food Science and Technology. 5 (I): 12-16.

Quinn R J. 1988. Chemistry of Aqueous Marine Extracts: Isolation Techniques in Bioorganic Marine Chemistry, Vol. 2.Verlag Berlin Heidelberg:Springer.

Raghu KL, Ramesh CK, Srinivasa TR, Jamuna KS. 2010. DPPH scavenging and reducing power properties in common vegetables. Research Journal of Pharmaceutical, Biological and Chemical Sciences. I (4):399-406.

Rahayu SE, Susanti R, Pribadi P. 2010. Perbandingan kadar vitamin dan mineral dalam buah segar dari manisan basah karika dieng (Carica pubescens Lenne dan K. Kock). Journal Biosaintifika. 2 (2): 90-I00.

Rachmawati, Deviani, Suriani. 2009. Pengaruh suhu dan penyimpanan terhadap kandungan vitamin $C$ pada cabe rawit putih (Capsicum frustenscens). Jurnal Biologi FMIPA Universitas Udayana. 13 (2): 36-40.

Sakong P, Khampitak T, Cha'on U, Pinitsoontorn C, Sriboonlue P, Yongvanit P, Boonsiri P. 201I. Antioxidant activity and bioactive 
phytochemical contents of traditional medicinal plants in northeast Thailand. Journal of Medicinal Plants. 5(3I): I-I0.

Salazar R, Perez LA, Lopez J, Alanis BA, Waksman N. 2009. Antimicrobial and antioxidant activities of plants from northeast of mexico. Evidence-Based Complementary and Alternative Medicine. 20 I I: I-6.

Salamah E, Ayuningrat E, Purwaningsih S. 2008. Penapisan awal komponen bioaktif dari kijing taiwan (Anadonta woodiana Lea.) sebagai senyawa antioksidan. Buletin Teknologi Hasil Perikanan. II(2): II9-I32.

Saupi N, Zakaria MH, Bujang J S. 2009. Analytic chemical compotition and mineral content of yellow velvetleaf (Limnocharis flava $L$. Buchenau)'s edible parts. Jurnal of Applied Sciences. 9(I6): 2969-2974.

Somsub W, Kongkachuichai R, Sungpuang P, Charoensiri R. 2007. Effect of three conventional cooking methods on vitamin c, tannin, myo-inositol phosphates contents in selected Thai vegetables. Journal of Food Composition and Analysis. 21: 187-197. 